\title{
Adolescents, Street, Drugs and Psychoactive Substances: A Study on Risk and Protection
}

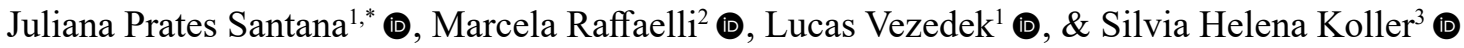 \\ ${ }^{1}$ Universidade Federal da Bahia, Salvador, BA, Brasil \\ ${ }^{2}$ University of Illinois at Urbana-Champaign, Champaign, IL, Estados Unidos \\ ${ }^{3}$ Universidade Federal do Rio Grande, Rio Grande, RS, Brasil
}

\begin{abstract}
The article describes the consumption of psychoactive substances (PSs) by street-involved children and adolescents (SCA) in three Brazilian state capitals and examines adverse life events due to drug involvement. The longitudinal study included 108 SCA (9-18 years old, both sexes), grouped according to the main reason for going to the street: drugs, caregivers, escape, work and freedom. It also discusses the impact of drugs, trafficking and the place that this theme has occupied in public policies, social interventions and the life trajectory of these participants, through a case study. It is intended that these data can support the operation of interventions and the formulation of public policies that guarantee integral protection.
\end{abstract}

KEYWORDS: adolescents, street, drugs, risk, protection

\section{Adolescentes, Rua, Drogas e Substâncias Psicoativas: Um Estudo sobre Risco e Proteção}

\begin{abstract}
RESUMO - O artigo descreve o consumo de substâncias psicoativas (SPAs) por crianças e adolescentes em situação de rua (CASR) em três capitais brasileiras e compreende os eventos de vida adversos decorrentes do envolvimento com as drogas. Participaram do estudo longitudinal 108 CASR (9-18 anos; ambos os sexos), agrupados de acordo com o principal motivo de ida para a rua: drogas, cuidadores, fuga, trabalho e liberdade. Discute, ainda, o impacto da droga, do tráfico e do lugar que este tema tem ocupado nas políticas públicas, nas intervenções sociais e na trajetória de vida destes participantes, através de um estudo de caso. Pretende-se que esses dados possam subsidiar a operacionalização de intervenções e a formulação de políticas públicas que garantam a proteção integral.
\end{abstract}

PALAVRAS-CHAVE: adolescentes, rua, drogas, risco, proteção

The goal of this article is to describe the consumption of psychoactive substances (PSs) among street-involved children and adolescents, based on a longitudinal study conducted in three Brazilian cities (Porto Alegre, Fortaleza and Salvador). It also presents a case study to illustrate the impact of drugs, trafficking and the place that this theme has occupied in public policies, social interventions, and the life trajectory of these youth.

Psychoactive substances are all those that generate changes in the nervous system, modifying its functioning and state of consciousness (Malbergier \& Amaral, 2013).
These include licit substances (alcohol, tobacco, over-thecounter or prescription drugs, among others) and illicit substances (marijuana, crack, cocaine, inhalants, heroin, among others). In contrast, the term drugs, which refers to a broader political, economic and social context, is often used in a pejorative way to refer to illicit substances, which are generally presented as a problem and its use is combated and criminalized (Feffermann et al., 2017).

In proposing the distinction between PSs and drugs, terms which are commonly used interchangeably, this article highlights the need to understand different facets of

*E-mail: julianapsantana@gmail.com

- Submetido: 17/10/2018; Aceito: 01/12/2020. 
a complex phenomenon. The concept of PSs encompasses substances and their effects, as well as consumption patterns, being addressed primarily in the field of health. The discussion on drugs, on the other hand, encompasses the social and rights spheres, here understood as the social issues that influence use; the operations of trafficking networks and their repercussions on social and community life; as well as legislation covering use, commercialization, and intervention.

That said, we consider the simultaneous investigation of PSs and drugs as critical, seeking to encompass consumption, its incidence among the homeless population, the impact of involvement with illegal activities and repressive policies, which together produce high levels of incarceration and assassination of poor youth, the majority of whom are Black (Waiselfisz, 2015). This is also evident in the Atlas of Violence 2020, which points to homicide as the main cause of death among young people, corresponding to $53.6 \%$ of all cases in the country. According to the study's findings relating to the Black population, for every non-Black person killed, 2.7 Black people were killed, representing 75.7\% of the total homicides (Institute for Applied Economic Research, 2020).

\section{Psychoactive Substances and Drugs: Different Debates and Complementary Risks}

Regarding the consumption of PSs among streetinvolved children and adolescents, data from Embleton et al. (2013) indicate that use varies according to geographic location, demonstrating its political, economic, and social character. On the basis of an analysis of 50 studies carried out in a range of lower income countries, including Brazil, the authors concluded that the most used PSs among streetinvolved children and adolescents are inhalants, followed by tobacco, alcohol, and marijuana.

The Brazilian context has been systematically researched by the Brazilian Information Center on Psychotropic Drugs (CEBRID; Noto et al., 1994, 1998; Noto et al., 2004). CEBRID's latest survey of street-involved youth showed increased consumption of PSs compared to previous studies. Tobacco (cigarettes) was the most commonly consumed PS, with the highest levels of lifetime use $(63.7 \%$ )(past year $52.5 \%$ and past month use $-44.5 \%$ ); followed by alcohol. Solvents were the most widely used illicit PS, being a common habit and characteristic of street-involved children and adolescents. According to Noto et al. (2004), unlike alcohol and tobacco, the consumption of solvents occurs after youth become incorporated into street life. With respect to crack, the availability and consumption of cocaine and its derivatives stand out in the Northeast region (Fortaleza and Recife), where recent consumption rates increased from $1.0 \%$ to $10.3 \%$ and $20.3 \%$, respectively, between 1997 and 2003.
A more recent study carried out in Salvador (Santana \& Vezedek, 2019), indicated that alcohol and tobacco remain the most commonly used PSs by street-involved children and adolescents. Rates of alcohol consumption were $67.5 \%$ (lifetime), 53.2\% (past year) and 41.6\% (past month); $41.6 \%$ of the children and adolescents had used tobacco in their lifetime, $33.1 \%$ in the past year, and $26.6 \%$ in the past month. According to the study, marijuana was the most widely used illicit PS (39.6\% of respondents reported lifetime use, 33.1\% past year use, and $30.5 \%$ past month use). Solvents were the fifth most commonly used PS (22.1\% lifetime, $17.5 \%$ past year, $13.0 \%$ past month), out of the seven PSs investigated.

Only a single study has identified crack as the most widely used illicit substance among street-involved children and adolescents (Oliveira et al., 2016). However, this has not prevented the media and the general public from creating and nurturing a belief in the "significant increase" in the number of users in this segment, especially due to the media's focus on so-called "cracolândias" ("crack lands") (Bastos \& Bertoni, 2014). This increase is not corroborated by the Brazilian national survey on crack use carried out by the Ministry of Health in 2012, which did not observe a significant number of children and adolescents at spaces of crack use (Bastos \& Bertoni, 2014).

The abusive use of PSs in adolescence results in different effects and damages from those observed in adults. Hall et al. (2016) state that such differences occur due to the psychological and neurochemical characteristics of adolescence. According to these authors, the use of substances can cause acute poisoning in the short term, with consequences for physical health and social interaction, and in the long term it can cause chemical dependency in adult life (Hall et al., 2016). Specifically with regard to street-involved children and adolescents, the World Health Organization (2000) highlights the possible physical, psychological, and social consequences of PS consumption. In addition, the World Health Organization emphasizes that the use of different PSs in combination can increase the risk of overdose and also of accidents, death, violence, and suicide.

Early research had already noted the involvement of street-involved children and adolescents with drugs, which were part of the reality of the street context. There was a distinction, however, between the study of these youngsters and those who were involved in trafficking, in terms of the psychosocial profile and/or the risks to which they were exposed. The approximation of these two groups can be seen in data from the 2015 Map of Violence in Brazil (Waiselfisz, 2015), which indicate that youth who were once on the streets are being killed/exterminated as a by-product or a consequence of violence exacerbated by involvement with drugs, here understood as the social issues that influence the use of PSs, the operations of the trafficking network, and their repercussions on social and community life. 
The growing overlap between these two areas of study ("street-involved children and adolescents" and "children and adolescents involved in trafficking networks") is justified by three questions. The first refers to increased use and change in types of PSs, primarily illicit ones, among street-involved children and adolescents. Whereas solvents are easily accessible and available on the "safe" (open) market, PSs like marijuana and crack are only accessible through the informal, illicit, market. In other words, the acquisition of these PSs is only possible through the retail trade of drugs classified as illicit or retail drug trafficking (Silva et al., 2006), which involves an aggregated set of risks (Souza, 2017).

The second question refers to the understanding that street involvement occurs not only in city centers, but also in the streets of peripheral (typically lower income) neighborhoods, and involvement with drug trafficking network is one of the ways of "being on the street." The increase in trafficking and involvement of children and adolescents in these networks means that youth no longer have to leave peripheral neighborhoods to access benefits such as consumer goods. In fact, involvement in the trafficking social network dictates the "limits of spatial mobility in the city" (Silva et al., 2006, p. 57), preventing those involved from circulating through the city center (Souza, 2017). It is necessary to broaden the view of the street, considering not only distance from place of residence but understanding that street involvement exists when the street is a space for the violation of rights (Rizzini et al, 2010).

The third question refers to the fact that death threats can result in children's expulsion from their communities of origin, causing them to leave for the streets of the city center and for the network of protection (Salatiel et al., 2017; Benício et al., 2018). This has made it evident to those who work with this population that street-involved children and adolescents, and youth involved with the drug trafficking network, cannot be considered completely distinct groups.

Even understanding the intersection of the use of PSs with street involvement, it is necessary to emphasize the effect of invisibility caused by the juxtaposition of these themes. Street involvement is no longer the focus of social and political concerns, being replaced by the "war against drugs," more specifically, against crack. The direct consequence of this is a change in the types of institutions and services that are created. Street-involved children and adolescents are no longer considered exclusively a social problem; instead, they become a public health problem and, more commonly, a legal problem, since in Brazil the "war on drugs" was and remains an issue of justice and fighting crime (Souza, 2017; Pimentel \& Silva, 2020).

\section{METHOD}

This article analyzes data from a longitudinal study on the developmental impact of street life conducted from 2012 to 2014. In order to obtain geographical diversity, data were collected in three Brazilian state capitals (Porto Alegre, Fortaleza, and Salvador). The study followed the principles of Resolution no. 196/96 of the CNS (Brazil) (Conselho Nacional de Saúde, 1996) in force at the time of data collection, respecting participants' autonomy, the voluntary character of participation, and the confidentiality of the data. Study procedures were approved by the Ethics Committees of the University of Illinois at Urbana-Champaign, Federal University of Rio Grande do Sul (Protocol No. 2011023; Registration Number: 25000.089325 / 2006-58), University of Fortaleza (Protocol No. 397/2011; CAAE: 0526.0.037.16511), and University of Salvador (Protocol no. 04.11.73; FR: 482281). The study was also presented to the State Public Prosecution Services of the three cities to ensure members of each city's care networks attending street-involved children and adolescents were aware of the study.

\section{Participants}

A total of 113 children and adolescents with current or recent street involvement (within the past year) participated in the study (39.8\% in Fortaleza, 35.4\% in Salvador and $24.8 \%$ in Porto Alegre). Participant demographics did not differ across the three cities. The current article considered 108 participants between the ages of $9-18$ years $(M=14.2$, $S D=2.44$ ) who had complete data on the use of PSs. The majority were male $(82.4 \%)$ and non-White $(91.6 \%)$. Participants were recruited from institutional care units (78.7\%), open services that provide care to children and adolescents on the streets (17.6\%), or on the street (3.7\%).

\section{Instruments}

Participants completed a set of measures that had previously been adapted and validated for use with streetinvolved children and adolescents (Santana et al., 2018). This article drew on the following instruments:

1. Life History Interview, consisting of five sections (personal and family history, leaving home, life on the streets, school and work experience, institutionalization history). Interview responses were used in conjunction with field diaries and tracking data to construct a Participant Form for each youth. This document included an assessment of the reason the youth went to the street and the intensity (strength) of their link to the street; intensity of contact and quality of bond with caregivers; types of institutions attended and the intensity of the 
youth's link with them; type and level of circulation between guardianship spaces.

2. Adverse Childhood Experiences were assessed with a checklist of 36 events assessing adversity in various domains (individual, socioeconomic, familiar, and related to violence). Each event that occurred received a value of one (1) and an overall score was computed by summing (Raffaelli et al., 2007).

3. Current Status Interview, covering nine dimensions reflecting youth's street involvement. For this article, we analyzed an item regarding involvement in the sale of drugs (part of a Subsistence Strategies scale) and multiple items reflecting use of PSs (adapted from Noto et al., 2004). Regarding the first item, participants reported how often they "Sold Drugs" during the last month on a scale of 1 (never) to 5 (always). Regarding the Use of PSs, youth reported their lifetime, past year, and last month use of alcohol, cigarettes, marijuana, solvents, cocaine and crack. A variable was also created to index the total number of PSs youth used in their lifetime by assigning a value of one (1) to each PS used and summing; a similar approach was used to index the total number of PSs used in the last year.

\section{Procedures}

Details of the study procedures were presented in Santana et al. (2018). In brief, the study was carried out in five stages: 1) shared training of the research teams (composed of undergraduate and graduate students), with the construction of a common protocol that was adapted, when necessary, to each city's context; 2) mapping of the service networks for at risk and socially vulnerable children and adolescents; 3) ecological engagement (Koller et al., 2016), a methodological strategy based on the Bioecological Theory of Human Development (Bronfenbrenner, 1996/1979), which consists of the engagement of researchers in participants' natural contexts, for prolonged periods of time, with the objective of establishing links and enhancing the ecological validity of the study; 4) data collection, which included recruiting the sample, applying structured instruments at three time points (T1, T2 and T3) spaced six months apart, and keeping track of participants between each assessment (tracking); and 5) systematization of data and dissemination of findings.

\section{RESULTS}

We first present a quantitative analysis of patterns of PS use and their relations with adverse childhood experiences and bonds with caregivers, the street, and institutions. This analysis used a categorization of youth based on the main reason for going to the street identified by the participants and researchers (Street Drugs, Street Caregivers, Street Escape, Street Work, and Street Freedom). Following this, we present a case study integrating quantitative and qualitative elements, to elucidate the impact of drugs and the use of PSs on a street-involved adolescent's life trajectory.

Table 1 displays consumption of PSs among participants. The most commonly used PSs by street-involved children and adolescents in their lifetime and in the past year were alcohol and cigarettes, followed by marijuana. Fewer participants reported using PSs in the last month, which may be due to the fact that most participants $(78.7 \%)$ were in institutional care units at the time of data collection.

In the sample as a whole, total types of PSs used in the last year were positively and significantly correlated with age $(r=0.36 ; p<0.01)$ and total number of adverse childhood experiences $(r=0.52 ; p<0.01)$. Comparisons of the three cities revealed significant differences in lifetime consumption of different types of PSs, the total of PSs used in the last year, and age of first consumption, with Fortaleza having the highest levels of consumption.

We also examined the association between reason for going to the street and aspects of the adolescents' life trajectories. Analysis of the participant forms allowed us

Table 1

Consumption of PSs: Reported use in Lifetime, Past Year, and Last Month and Age of First Consumption

\begin{tabular}{lcccc}
\hline \multicolumn{1}{c}{ PSs } & Use in lifetime (\%) & Age of 1st consumptiona (M / SD) & Use in past year (\%) & Use in last month (\%) \\
\hline Cigarettes & 77.8 & $11.11 / 2.40$ & 59.9 & 39.3 \\
Alcohol & 75 & $11.31 / 2.67$ & 54.2 & 28 \\
Marijuana & 67.6 & $11.66 / 2.14$ & 50 & 35.2 \\
Cocaine & 49.1 & $12.35 / 2.36$ & 31.5 & 10.2 \\
Solvents & 31.5 & $12.19 / 3.32$ & 15.4 & 8.7 \\
Crack & 26.7 & $11.82 / 2.37$ & 15.4 & 5.8 \\
\hline
\end{tabular}

Note. ${ }^{\text {a }}$ Among those who consumed PSs. 
to categorize youth into five groups based on the main reason for going to the street identified by them and by the researchers. For the "Street Drugs" group ( $28.4 \%$ of sample), the reason for going to the street was directly linked to the use/abuse of PSs and/or participation in trafficking; in some cases, adolescents received death threats because of their involvement in trafficking and took to the street or sought institutional care. "Street Caregivers" (18.3\%) included cases where going to the street was related to a family history of street experience or where the youth's caregivers or even entire family were on the street. The category "Street Escape" (22.9\%) was used when a child was "expelled" from home due to factors such as parental death or imprisonment, violence, negligence, etc. Youth who went to the street to perform some income-generating activity, whether working or begging, were categorized as "Street Work" (11\%). Lastly, "Street Freedom" (19.3\%) included cases in which the respondent was attracted to the street by the freedom it represents (possibility of experiencing sexuality, escaping the rules of the house, getting away from sibling caretaking or household responsibilities, etc.).
Because this article aims to examine how relations with drugs influences the life trajectories of street-involved children and adolescents, comparative analyses were conducted using the Street Drugs category as the reference group. There were no differences in gender or city of collection between the five groups, but significant age differences $(p<0.05)$ were found between the Street Drugs $(M=15.40, S D=1.66)$ and Street Caregivers $(M=12.50$, $S D=2.52$ ) groups.

Comparisons between the groups are displayed in Table 2 . The total number of PSs used by youth in their lifetime was significantly higher in the Street Drugs group, as compared to Street Caregivers and Street Freedom. Youth in the Street Drugs group reported using significantly more total types of PSs in the last years than those categorized as Street Caregivers, Street Escape, or Street Work. The Street Drugs group had greater involvement in the sale of drugs compared to the Street Caregivers, Street Escape, and Street Freedom groups. Of the other variables analyzed, intensity of contact with caregivers was greater in the Street Drugs group than in the Street Escape group.

Table 2

Comparisons between Reason for going to the Street Groups: Use of PSs, Adverse Childhood Experiences, Intensity of the Bond with Caregivers, the Street and Institutions

\begin{tabular}{lccccc}
\hline & $\begin{array}{c}\text { Street Drugs } \\
(\mathbf{D})\end{array}$ & $\begin{array}{c}\text { Street Caregivers } \\
(\mathbf{C})\end{array}$ & $\begin{array}{c}\text { Street Escape } \\
(\mathbf{E})\end{array}$ & $\begin{array}{c}\text { Street Work } \\
(\mathbf{W})\end{array}$ & $\begin{array}{c}\text { Street Freedom } \\
(\mathbf{F})\end{array}$ \\
\hline Total types of PSs used in lifetime & $4.67(1.68)^{\mathrm{C}, \mathrm{F}}$ & $2.26(2.44)^{\mathrm{D}, \mathrm{E}}$ & $3.65(2.39)^{\mathrm{C}}$ & $3.75(1.91)$ & $3.15(2.00)^{\mathrm{D}}$ \\
Total types of PSs used in last year & $3.54(1.66)^{\mathrm{C}, \mathrm{E}, \mathrm{W}}$ & $0.89(1.59)^{\mathrm{D}, \mathrm{E}, \mathrm{F}}$ & $2.38(2.18)^{\mathrm{D}, \mathrm{C}}$ & $1.83(2.20)^{\mathrm{D}}$ & $2.45(1.99)^{\mathrm{C}}$ \\
Sold drugs & $2.96(1.73)^{\mathrm{C}, \mathrm{E}, \mathrm{F}}$ & $1.42(1.12)^{\mathrm{D}}$ & $1.90(1.54)^{\mathrm{D}}$ & $2.25(1.66)$ & $1.65(1.23)^{\mathrm{D}}$ \\
Adverse Events in Childhood & $16.24(3.81)$ & $16.2(5.06)$ & $18.25(3.69)$ & $17(5.25)$ & $15.71(4.97)$ \\
Intensity of bond with caretakers & $1.96(0.73)^{\mathrm{E}}$ & $2.1(0.79)^{\mathrm{E}}$ & $1.32(0.54)^{\mathrm{D}, \mathrm{C}, \mathrm{F}}$ & $1.91(0.79)$ & $1.90(0.70)^{\mathrm{F}}$ \\
Intensity of bond with the street & $2.36(0.63)$ & $2.4(0.75)$ & $1.61(0.71)$ & $2(0.43)$ & $2.38(0.74)$ \\
Intensity of bond with institutions & $1.6(0.70)$ & $1.9(0.85)$ & $1.61(0,71)$ & $1.92(0.79)$ & $1.57(0.75)$ \\
\hline
\end{tabular}

Note. The superscript letters reflect the differences between the groups represented in the columns and the groups designated by the superscript letters.

\section{DISCUSSION}

A significant number of participants (85.2\%) used at least one PS in their lifetime. This finding is consistent with data from national (Bastos \& Bertoni, 2014; Neiva-Silva, 2008; Noto et al., 2004; Oliveira, 2016; Santana \& Vezedek, 2019; Silvestre \& Carvalho, 2016) and international (Embleton et al., 2013; Hills et al., 2016; Paul et al., 2020; Tyler et al., 2016) studies that show a high consumption of PSs among street-involved children and adolescents. Tobacco and alcohol were the PSs most often used by study participants, which is similar to results presented by Noto et al. (2004) and Santana and Vezedek (2019) on the use of PSs by streetinvolved children and adolescents. However, regarding the third most used PS, our sample reported a greater incidence of marijuana as found by Neiva-Silva (2008). In the studies by Noto et al. (2004) and Santana and Vezedek (2019) the third most used SPA is solvent.

The finding that tobacco and alcohol were the most commonly used PSs (lifetime and past year) is consistent with research conducted by Neiva-Silva (2008), Noto et al. (2004), and Santana and Vezedek (2019). It is noteworthy that marijuana was the second most used PS in the last month, unlike these previous studies where alcohol occupied this position. In both our sample and the three studies mentioned above, crack was the least used substance in the last month. In contrast, Oliveira et al. (2016) found that crack was the second most used PS (44.4\%) among street-involved children and adolescents in the city of São Paulo, followed by tobacco $(75.3 \%)$. 
Another relevant piece of information is the average age for the first use of PSs, identified in the survey as around 11.8 years of age. The earlier youth have contact with PSs, the more harmful their effects are in biopsychosocial terms, irrespective of considering the Theory of Progression in Substance Use or Gateway Theory, which states that the use of PSs follows a progression starting with alcohol and tobacco, followed by marijuana and other illicit drugs (Kandel et al, 1992).

With respect to the analyses examining reasons for going to the street and the participants' life trajectories, it is worth noting that one of this study's contributions is that it proposed a way to categorize street experience based on the main reason for going to the street. It is known that the street experience is unique across individuals, but the proposed typology can be used as a basis for planning specific interventions. The distinction between the Street Drugs, Street Caregivers, Street Escape, Street Work, and Street Freedom groups is not only of theoretical value, but also empirically significant as it allows for a more contextualized understanding of the street experience of children and adolescents.

This group analysis revealed that drugs were the main reason for more than a quarter of the sample being on the street (28.4\%). Youth in this group consequently had a greater involvement with drugs, both with regard to use and sale of PSs. Thus, it is worth highlighting the involvement of this group of adolescents with the drug trafficking network and repressive policies, which has been linked to alarming statistics on deaths from violence and firearms (Silva et al., 2006; Waiselfisz, 2015; Souza, 2017).

Regarding the intensity of bonds with caregivers, the only significant difference observed was between the Street Drugs and the Street Escape group. This contradicts the common notion that adolescents involved with drugs do not have family ties. This finding is crucial in a context such as that of the city of Salvador, in which a government campaign uses the slogan "More Family, Less Drugs" (Government of Bahia, 2015), as if families were exclusively to blame for the use of PSs by their sons and daughters, disregarding the need to implement public policies in the economic and social spheres.

\section{The Case of Carolina':When Punishment Overcomes Protection}

A case study of an adolescent girl from the Street Drugs group was conducted in order to integrate quantitative and qualitative elements that would make it possible to understand the impact of the use of PSs and drugs on her life trajectory. Risk and protective factors present in the participant's developmental contexts were analyzed, as well

1 Pseudonym to protect participant's privacy. as the role of public policies or absences and gaps identified in her network of protection.

Carolina was 13 years old when she began participating in the research study. She was a thin girl of average height, considered parda ("brown"; a term used by the Brazilian Census to describe people of mixed ethnic background) by the researchers, with hair dyed red. She was followed up by the researchers for a period of eighteen consecutive months, following the study protocol which involved the completion of measures at three time points (T1, T2, T3). Twelve months later, in a second stage of the investigation, information was obtained about the adolescent, now 15 years old, through the social protection network (staff at care institutions and the Guardianship Council), from family members, and her former companion.

Throughout her life, Carolina used six PSs (alcohol, cigarettes, marijuana, cocaine, crack, and pitilho, a mixture of crack and marijuana); of these, only crack was not used in the last year. The consumption onset age was 10 years old for cigarettes and 11 years old for the other PSs. She experienced a total of 16 adverse childhood events, namely: "high levels of conflict at home"; "Family member seriously injured or ill"; "Death of sister(s) or brother(s)"; "Lack of food or basic necessities"; "Physical violence by family members and non-family members"; "Sexual violence by a non-family member"; "Hospitalized due to an injury or accident"; "Did poorly at school (had to repeat the year)"; "Expelled or suspended from school"; "Left school to help the family"; "Was sheltered [institutionalized]"; "Slept in the street"; "Stopped living with the family"; "Was attended by the Guardianship Council"; and "Suffered death threats." Responding to the item "sold drugs" from the subsistence strategies scale, Carolina chose the option "sometimes."

When evaluating Carolina's bonds with different development contexts, we found a strong bond with the street and a weak bond with the institutions she frequented. Links with caregivers were emotionally fragile. In addition, the intensity of contact with caregivers was characterized as average, since contact was intermittent, alternating with the street and service institutions. Throughout her trajectory, Carolina circulated frequently between the street, institutions, and caregivers' home.

In order to help understand Carolina's complex life trajectory and her movement through different contexts (family, streets, and institutions), Figures 1 and 2 were constructed. These figures use a timeline to illustrate the main events in Carolina's life from her birth until the end of the study. We sought to explicate the relations between development contexts (represented by geometric shapes) based on each piece of information that was collected.

Carolina was abandoned by her family of origin and adopted when she was three months old by an elderly couple that already had a son. She started her street experience at the age of ten, at the same time she began experimenting with PSs. Her use intensified when she was 11 which, 


\section{From birth to 11 years old}

\section{FAMILY}

- Carolina is born in an interior area of a Northeastern state.

- She is abandoned by her family of origin.

- At three months of age she is adopted by an elderly couple who have a son.

\section{2 years old}

\section{STREET 1 CITY OF ORIGIN}

- Carolina sleeps on the street for the first time.

- She spends long periods of time on the street, despite still living at her family's house.

- Abusive sexual relationship with an adult man involved in drug trafficking.

\section{3 years old}

\section{INSTITUTION 1
CAPITAL STATE OF ORIGIN}

- First institutionalization (reason not disclosed by Carolina).

- A few days later, she runs away for the first time from the institutional care unit [unauthorized departure] during the carnival period.

- She returns to the institutional care unit because she learns from a TV show that her family is looking for her.

- She runs away from the institutional care unit and hitches a ride to the capital of another state in the Northeast Region (State 2).

\section{INSTITUTION 2}

\section{CITY 3}

- Carolina is referred by the Guardianship Council (State 2) to a institutional care unit in City 3 due to the intensification of PS use.

- The Guardianship Council sends the teenager to her hometown.

\section{FAMILY}

- Initiates use of Psychoactive Substances (PSs) and street experience at 10 years old.

- Abusive use of PSs at age of 11.

- Experiences of physical aggressions in the family environment as an attempt to restrict the use of PSs.

- Separates from school.

\section{STREET 2}

\section{CAPITAL STATE OF ORIGIN}

- She runs away from home and hitches a ride to the state capital.

- Sleeps and asks for food and money on the streets; considers herself a "street youth" now.

- Goes to live with the family of a teenager she meets on the beach in exchange for food and "help" with household tasks. This family's home is located in a neighborhood with intense drug trafficking

- Her involvement with, and attachment to, the street intensifies.

\section{STREET 3}

CAPITAL OF STATE 2 OF THE NORTHEAST REGION - 6 MONTH PERIOD

- She stays at a boyfriend's house.

- Passes through several institutional care units (did not know the exact number).

- Intense use of PSs.

- Has difficulties remaining engaged with institutional care units because of the use of PSs, aggressive behavior and history of unauthorized departures.

- During this period, she is intensely involved with the street and its influence prevails (City 2).

\section{FAMILY}

- Beginning of searches for treatment for the abusive use of PSs in the interior and in the capital, with support from the research team.

- Involvement with drug trafficking and first death threat received due to abusive sexual relationship with a drug dealer.

- She runs away from her family's house. 


\section{3 years old}

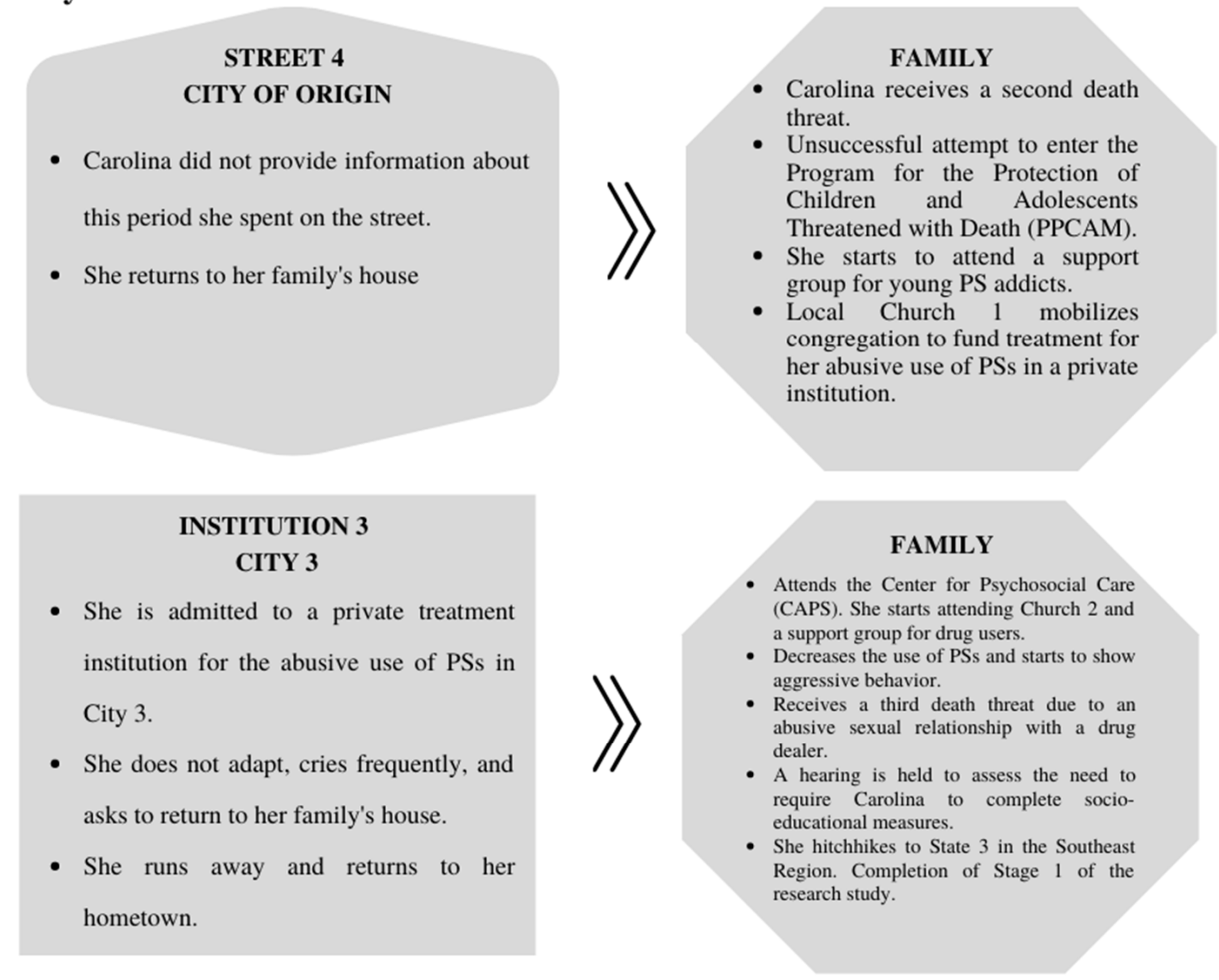

\section{5 years old (information obtained through family members, ex-partner and service network) STEP 2 OF THE RESEARCH}

\section{INSTITUTIONAL ROUTE IN THE CAPITAL OF THE STATE OF ORIGIN}

- Institutional care unit 4.

- Spent time in government facility while waiting for shelter.

- Institutional care unit 5.

- Instituição 5 - UAI.

- Institutional care unit 6 , where she is diagnosed with syphilis.

- Attends the Psychosocial Care Center for Alcohol and other Drugs (CAPS-AD).

- Institutional care unit 7.

- She runs away and hitchhikes to City 4.

\section{STREET 6}

\section{STATE 4 OF THE SOUTHEAST REGION}

- Involvement with drug trafficking.

- Receives a death threat for the fifth time.

- Gets back in touch with the family.

\section{STREET 5}

CITY 4

- Involvement with drug trafficking.

- Receives a fourth death threat.

- Is a victim of rape.

- She hitchhikes to State 4 of the Southeast Region

\section{STATE 5 OF THE SOUTHEAST REGION}

- The family hospitalizes her in a treatment center for abusive use of PSs.

- Harm reduction - she was using only ordinary cigarettes.

- Completion of Stage 2 of the research study. 
according to Carolina, led to family conflicts, as her mother and brother started to use physical force to prevent her from leaving the house. The family decided to move to a smaller city, seeking to change the situation; this proved ineffective, however, since the same behaviors continued. The family returned to their city of origin, but the changes resulted in the adolescent's permanent break with school. There were other reasons in addition to the use of PSs as the adolescent reports:

I ran away from home to be with my boyfriend. Then there were days when I was hanging out on the street. I even slept on the street ... I also didn't like doing work inside the house, I wanted to stay on the street, you know? (Interview T1).

At age 12, Carolina fled to the capital of her home state in the company of a female friend, claiming to be looking for treatment for drug addiction. This experience led her to take on the identity of a street youth, as she had to beg for food and money from passers-by. After a period sleeping on the street, she met a girl who took her home and whose mother offered housing and food in exchange for "help" with household chores. In the neighborhood where she went to live, Carolina became involved with the drug trafficking network as a way to earn money and support her PS use, as she described: "Then I stayed there ... there was drug trafficking .... then I went to smoke drug with the boys" (Interview T1). During this time her street experience was intense, and the institutionalization process was also initiated, marked, above all, by a high number of unauthorized departures.

Up to the time she began the research study, Carolina had been in approximately nine institutions in different cities and states, some for the treatment of abusive use of PSs and others for residential settings. However, it became increasingly difficult for Carolina to obtain placements or remain in institutional contexts. According to information obtained from the Guardian Counselor, "Because of her frequent departures, intense use of PS, and aggressive behavior, [Carolina] started to find it difficult to be accepted in institutions and stayed on the street" (Guardian Counselor, personal communication, September 13, 2013). The last information obtained about Carolina was that she had been admitted to a residential PS abuse treatment center in a Southeastern state. It is worth emphasizing that Carolina's life was marked by numerous risk factors related to the street, but mainly by her involvement with drugs and the abusive use of PSs. In addition to the previously described risks, Carolina suffered four death threats due to her involvement with trafficking, and she was sexually assaulted and contracted a sexually transmitted infection.

\section{Discussion of Case Study}

The case of Carolina can be understood, specifically with regard to developmental contexts, from the four systems proposed by Urie Bronfenbrenner (1996/1979), namely: microsystem, mesosystem, exosystem, and macrosystem. According to the author, the microsystem consists of those contexts in which the developing person establishes faceto-face relationships; in the case of Carolina, it is possible to mention the family, the various host institutions she frequented, and the street. The mesosystem does not refer to a specific context, but rather to linkages between the different microsystems. According to Bronfenbrenner (1996/1979), the mesosystem can enhance or hinder the developmental process, and in the case of Carolina there was a constant clash between contexts. There was little coordination or consistency between different contexts that made it possible, for example, to integrate care. In fact, the relations between the microsystems frequented by Carolina are marked by tensions, ruptures, and discontinuities. The links between development contexts were markedly fragile, with the street always functioning as the main context of attraction, either due to involvement with drugs or due to its characteristic of "unconditional acceptance." It can be said that the street, despite presenting numerous rules of coexistence and the violence involved, always welcomes.

The exosystem is characterized by contexts in which the developing person is not present, but which have a direct impact on their development. In the case of Carolina, one can consider policies for the care of street-involved children and adolescents who use PSs, or more precisely the absence of these public care policies. Each refusal of care and lack of coordination between elements of the service network, resulting from the absence of investment in the service area, is an example of action within the exosystem.

Finally, the macrosystem is defined by the macrosocial context, by the set of values and beliefs of a society. In the case of Carolina, these refer, for example, to prejudice, stigmatization about the uses and users of PSs, as well as structural racism.

This case study highlights several gaps in the safety net or opportunities for interventions that could strengthen and expand care for Carolina and her family. Her school was unable to intervene at the time when the use of PSs was recreational and the family did not have the support of the regional Social Assistance Reference Center (Centro de Referência de Assistência Social; CRAS) or the Specialized Social Assistance Reference Center (Centro de Referência Especializado de Assistência Social; CREAS) to help intervene when Carolina was still living at home. Despite the overlapping reasons for going to the street, it is possible to consider Carolina's abusive use of PSs and involvement with drugs as a central factor. According to Ramaldes et al. (2016), the sale of PSs is a factor that is 
associated with consumption "since the commercialization of substances represents a means of guaranteeing one's own consumption" (p.6).

Carolina's family remained involved throughout the adolescent's trajectory, seeking care options and not "giving up" on their daughter. They actively looked for her during episodes of escape to the street, constantly seeking treatment institutions for her abusive use of PSs and protection options when she was threatened with death. But at the same time, perhaps due to lack of information or lack of strategies to face the situation, the family used violence as a way to keep the adolescent at home and that was one of the reasons she gave for running away. These data corroborate the statement by Henriques et al. (2016, p. 7) that "the family context should be considered as an environment that operates as both a protective factor and a risk factor."

After Carolina left home, with her abusive use of PSs and involvement with the trafficking network, the absence or failure of the safety net became even more evident. There were numerous institutionalizations followed by successive refusals of service. Carolina's case demonstrates the challenges of ensuring that the rights of adolescents who use psychoactive substances are protected, and this difficulty was often reported by professional staff at the institutions where the study was conducted. On the one hand, the institutions claimed that Carolina repeatedly "ran away"; on the other hand, it can be said that the institutions simultaneously closed their doors to the adolescent. Instead of facilitating and encouraging Carolina's engagement when she asked for help, they claimed that because of her previous departures or history of aggression, Carolina could no longer enter. It is as if the scarce resources, precarious working conditions, and difficulties of dealing with this population, made the institutions "vindictive." In light of these challenges, they accept and limit themselves to dealing with "possible and deserving" cases, that is, those who readily submit to institutional rules and do not leave without permission. However, Carolina is representative of a group of youth who need comprehensive and willing services. It is necessary to be able to deal with the numerous relapses and evasions, as this is characteristic of the population to be served (Santana \& Vezedek, 2020).

\section{FINAL CONSIDERATIONS}

The relations children and adolescents have with PSs and drugs is a complex issue that is difficult to analyze. The findings presented in this article demonstrate the importance of considering the multiplicity of risk factors involved in adolescents' life trajectory, with the use of PSs or involvement with the drug trafficking network just one of those risks. The lack of early interventions to help families, as well as institutional failures and absences, are evident in the case study we presented. The rights protection network has been shown to be inefficient in most cases (Neiva-Silva et al., 2010), as these require intervention in different contexts and at different levels (Petersen et al., 2016). Further research is needed to explore this issue in greater depth. In the case of Carolina, it was possible to identify some protective factors that minimized the risks of involvement with PSs and trafficking. It is worth highlighting her family's investment, with the frequent search for "solutions" and treatment alternatives, and perhaps the adolescent's involvement in the research study, which provided an additional element in the support network.

The concept of street as risk was used in this work, which meant that the research participants were those who used urban spaces not only for circulation and entertainment, but for whom those spaces constituted a risk. This means that in the present study, youth's involvement with the sale or use of psychoactive substances in their neighborhoods of origin was characterized and considered a street situation, as were their experiences of violence and sexual exploitation, even when referred to by teenagers as dating or consensual romantic involvement. This supports the notion that there is a continuum of risk and protective factors involved in individuals' life trajectories and that the street is just one of them.

In this sense, it is worth noting the value of moving beyond an analysis of the type of family bond or the activities adolescents engage in on the streets, to understand a complex system of relationships that occur in the context of the street. At the same time, in order to avoid the random inclusion of street-involved participants, it is necessary to systematize the elements that configure the street as a developmental risk.

There is an urgent need to stop treating the engagement of street-involved youth with PSs and drugs as a problem of justice, which leads to a series of rights violations and often culminates in their murder. It is important to invest in prevention approaches that treat this issue not as an individual problem but that consider all the social, economic, and political factors involved in the production of the street phenomenon. Only then will it be possible to guarantee that punishment for the use of PSs and drug involvement does not overcome the protection of these children and adolescents.

The present study had some methodological limitations, such as: 1) greater than desirable sample loss; 2) unknown participation rate, despite the rigorous recruitment strategy, which reduces the ability to generalize the findings; and 3) use of a predominantly male and non-White convenience sample. Due to this last aspect, it was not possible to conduct quantitative tests of racial differences in PS use, since 92\% of the sample was non-White. The last national survey on the use of PSs by street-involved children and adolescents (Noto et al., 2004) did not examine racial characteristics, 
only sex and age. However, it should be noted that other studies of the homeless population have involved samples with a similar racial composition as the current study. This can be considered a reflection of structural racism, which causes poverty and situations of risk and vulnerability in Brazil to affect, above all, the black population.

One of the main contributions of the present work is the development of an approach to characterizing the population of children and adolescents on the streets, considering primarily the main reason for going to the streets identified by them and the researchers. Using this approach, it was possible to understand the magnitude of involvement with drugs and the early and high use of PSs by these children and adolescents. Such involvement has been repeatedly decried by those who work in the care and protection network for homeless populations, and it is important to verify this information through empirical data.

We hope that the findings and discussions presented here can serve as a resource for professionals working with this population, as well as for managers, in order to enable a deeper understanding of the role that PSs and drugs have in the lives of these children and adolescents. Ultimately, these data can support the development of interventions and the formulation of care policies that are guided by the results of scientific research rather than by prejudices and stigmas that surround youth's relations with drugs.

\section{REFERENCES}

Bastos, F. I., \& Bertoni, N. (2014). Pesquisa nacional sobre o uso de crack: quem são os usuários de crack elou similares do Brasil? Quantos são nas capitais brasileiras? Editora ICICT/ FIOCRUZ.

Benício, L. F. S., Barros, J. P. P., Rodrigues, J. S., Silva, D. B., Leonardo, C. dos S., \& Costa, A. F. da. (2018). Necropolítica e Pesquisa-Intervenção sobre Homicídios de Adolescentes e Jovens em Fortaleza, Ceará. Psicologia: Ciência e Profissão v. 38 (esp. 2), 192-207. https://doi.org/10.1590/19823703000212908

Conselho Nacional de Saúde. (1996). Resolução $n^{\circ} .196$ de 10 de outubro de 1996. Ministério da Saúde.

Bronfenbrenner, U. (1996). A ecologia do desenvolvimento humano: Experimentos naturais e planejados. Artes Médicas. (Original paper published in 1979)

Embleton, L., Mwangi, A., Vreeman, R., Ayuku, D., \& Braitstein, P. (2013). The epidemiology of substance use among street children in resource-constrained settings: A systematic review and meta-analysis. Addiction, 108(10), 1722-1733. https://doi. org/10.1111/add.12252

Feffermann, M., Figueiredo, R., \& Adorno, R.C.F. (2017). Drogas e Saúde Pública: Uma relação política e complexa. In R. Figueiredo, M. Feffermann \& R. C. F. Adorno (Orgs.), Drogas \& Sociedade Contemporânea: Perspectivas para além do proibicionismo ( $1^{\text {a }}$ ed., pp. 11-19). Instituto de Saúde.

Governo da Bahia. (2015). Mais Família, Menos Drogas [Vídeo]. Governo da Bahia. Youtube. https://www.youtube.com/ watch? $\mathrm{v}=\mathrm{I} 2 \mathrm{HHJ} 9 \mathrm{sCVk}$

Hall, W. D., Patton, G., Stockings, E., Weier M., Lynskey, M., Morley, K. I., \& Degenhardt, L. (2016). Why young people's substance use matters for global health. The Lancet Psychiatry, 3(3), 265-279. https://doi.org/10.1016/S2215-0366(16)000134

Henriques, B. D., Rocha, R. L., \& Reinaldo, A. M. S. (2016). Uso de crack e outras drogas entre crianças e adolescentes e seu impacto no ambiente familiar: Uma revisão integrativa da literatura. Texto \& Contexto - Enfermagem, 25(3), e1100015. https://doi.org/10.1590/0104-07072016001100015

Hills, F., Meyer-Weitz, A., \& Asante, K. O. (2016). The lived experiences of street children in Durban, South Africa: Violence, substance use, and resilience. International Journal of Qualitative Studies on Health and Well-being, 11(1) 30302. https://doi.org/10.3402/qhw.v11.30302

Instituto de Pesquisa Econômica Aplicada. (Org.). (2020). Atlas da violência 2020. IPEA; FBSP. https://www.ipea.gov.br/ portal/index.php?option $=$ com content $\&$ view $=$ article $\&$ id $=36$ 488\&Itemid $=432$

Kandel, D. B., Yamaguchi, K., \& Chen, K. (1992). Stages of progression in drug involvement from adolescence to adulthood: Further evidence for the gateway theory. Journal of studies on alcohol, 53(5), 447-457. https://doi.org/10.15288/ jsa.1992.53.447

Koller, S. H., Morais, N. A., \& Paludo, S. S. (Orgs.) (2016). Inserção ecológica: Um método de estudo do desenvolvimento humano. Pearson Clinical Brasil.

Malbergier, A., \& Amaral, R. A. (2013). Conceitos básicos sobre o uso abusivo e dependência de drogas. In IV Curso de Especialização em Dependência Química. UNASUS/UFMA https://ares.unasus.gov.br/acervo/html/ARES/2046/3/Mod\%20 03\%20UNIDADE\%2001.pdf

Neiva-Silva, L. (2008). Uso de drogas entre crianças e adolescentes em situação de rua: um estudo longitudinal. [Tese de Doutorado, Universidade Federal do Rio Grande do Sul]. UFRGS Lume Repositório Digital. https://lume.ufrgs.br/ handle/10183/13708

Neiva-Silva, L., Marquardt, J. P., López, J., \& Koller, S. H. (2010). Uso de drogas por crianças e adolescentes em situação de rua e a busca de intervenções efetivas. In N. A. Morais, L. Neiva-Silva \&. S. H. Koller (Orgs.), Endereço desconhecido: Crianças e adolescentes em situação de rua (pp. 325-357). Casa do Psicólogo.

Noto, A. R., Galduróz, J. C. F., Nappo, S. A., Fonseca, A. M., Carlini, C. M. A., Moura, Y. G., \& Carlini, E. A. (2004). Levantamento nacional sobre o uso de drogas entre crianças e adolescentes em situação de rua nas 27 capitais Brasileiras - 2003. CEBRID; UNIFESP. https://www.cebrid.com.br/ category/livros/page/3/

Noto, A. R., Nappo, S., Galduróz, J. C. F., Mattei, R., \& Carlini, E. A. (1994). III levantamento sobre o uso de drogas entre crianças e adolescentes em situação de rua de cinco capitais brasileiras - 1993. CEBRID; Escola Paulista de Medicina. https://www.cebrid.com.br/category/livros/page/3/

Noto, A. R., Nappo, S., Galduróz, J. C. F., Mattei, R., \& Carlini, E. A. (1998). IV levantamento sobre o uso de drogas entre crianças e adolescentes em situação de rua de seis capitais brasileiras - 1997. CEBRID; Escola Paulista de Medicina. https://www.cebrid.com.br/category/livros/page/3/

Oliveira, M. A. F., Gonçalves, R. M. D. A, Claro, H. G., Tarifa, R. R., Nakahara, T., Bosque, R. M., \& Silva, N. N. (2016). Perfil das crianças e adolescentes em situação de rua usuários de 
drogas. Revista de enfermagem UFPE 10(2), 475-484. https:// doi.org/10.5205/1981-8963-v10i2a10979p475-484-2016

Paul, B., Thulien, M., Knight, R., Milloy, M. J., Howard, B., Nelson, S., \& Fast, D. (2020). "Something that actually works": Cannabis use among young people in the context of street entrenchment. PLoS ONE, 15(7), 0236243. https://doi. org/10.1371/journal.pone.0236243

Petersen, A., Koller, S. H., Motti-Stefanidi, F., \& Verma, S. (2016). Global equity and justice issues for young people during the first three decades of life. In S. S. Horn, M. D. Ruck, \& L. S. Liben (Eds.), Advances in child development and behavior: Vol. 51. Equity and justice in developmental science: Implications for young people, families, and communities ( $\mathrm{p}$. 289-320). Elsevier Academic Press. https://doi.org/10.1016/ bs.acdb.2016.05.006

Pimentel, R. F., \& Silva, M. C. C. (2020). Atenção às pessoas em situação de rua que também fazem uso de drogas: Um cuidado orientado pelos princípios da redução de danos e da reforma psiquiátrica antimanicomial. In A. M. Gonçalves, A. C. G. Bastos \& L. Vezedek (Orgs.), Caderno de forma-ação e navegação social projeto Caboré: Diagnóstico, capacitação, assistência técnica, monitoramento e difusão de conhecimentos ( $1^{\text {a }}$ ed., pp. 54-67). Centro Projeto Axé.

Raffaelli, M., Koller, S. H., \& Morais, N. A. (2007). Assessing the development of Brazilian street youth. Vulnerable Children and Youth Studies, 2(2), 154-164. https://doi. org/10.1080/17450120701403128

Ramaldes, H. Q., Avellar, L. Z., \& Tristão, K. G. (2016). Características de crianças usuárias de substâncias psicoativas descritas pela própria criança. Psicologia: Teoria e Pesquisa, 32(4), e324220. https://doi.org/10.1590/0102.3772e324220

Rizzini, I. Caldeira, P., Ribeiro, R., \& Carvano, L. M. (2010). Crianças e adolescentes com direitos violados: situação de rua e indicadores de vulnerabilidade no Brasil urbano. PUCRio; CIESPI.

Salatiel, E. L., França, C. de A., Resende, J. M., \& Guimarães, R. L. (2017). Desafios da proteção a crianças e adolescentes ameaçados de morte no Brasil. Revista Latinoamericana de Ciencias Sociales, Niñez y Juventud, 15(2), 1123-1135. http:// dx.doi.org/10.11600/1692715x.1522220092016

Santana, J. P., Raffaelli, M., Koller, S. H., \& Morais, N. A. (2018). "Vocês me encontram em qualquer lugar": Realizando pesquisa longitudinal com adolescentes em situação de rua. Psico, 49(1), 31-42. https://doi.org/10.15448/1980-8623.2018.1.25802

Santana, J. P., \& Vezedek, L. (2019). Cartografias dos desejos e direitos: Caracterização e modos de vida de crianças e adolescentes em situação de rua na cidade de Salvador/BA.
In I. G. Barbosa \& M. A. Soares (Orgs.), Por uma luta sem fronteira na defesa dos direitos das crianças: Políticas públicas e participação (pp. 500-512). Editora Vieira.

Santana, J. P., \& Vezedek, L. (2020). Sistematizando tecnologias de cuidado: O acolhimento e acompanhamento da população em situação de rua. In A. M. Gonçalves, A. C. G. Bastos \& L. Vezedek (Orgs.), Caderno de forma-ação e navegação social projeto Caboré: Diagnóstico, capacitação, assistência técnica, monitoramento e difusão de conhecimentos ( $1^{\mathrm{a}} \mathrm{ed} ., \mathrm{pp}$. 54-67). $^{2}$. Centro Projeto Axé.

Silva, J. S, Braga, R. W., Rodrigues, F. S., Fernandes, F. L., \& Silva, E. S. (2006). Caminhada de crianças, adolescentes e jovens na rede do tráfico de drogas no varejo do Rio de Janeiro, 2004-2006 - Sumário Executivo. Observatório de Favelas. http://observatoriodefavelas.org. br/wp-content/uploads/2013/12/TRAJET\%C3\%93RIA-DECRIAN\%C3\%87AS-ADOLESCENTES-E-JOVENS-NAREDE-DO-TR\%C3\%81FICO-DE-DROGAS-NO-VAREJODO-RIO-DE-JANEIRO-2004-2006.pdf

Silvestre, T. C., \& Carvalho, M. H. (2016). Perfil social de crianças e adolescentes em situação de rua em Manhuaçu/MG. In: Anais do II Seminário Científico do UNIFACIG (N. 2, pp. 01-11). UNIFACIG. http://pensaracademico.facig.edu.br/index.php/ semiariocientifico/article/view/224

Souza, J. S. (2017). Efeitos colaterais da estratégia de "guerra às drogas", a falência das unidades policiais pacificadoras do rio de janeiro e o aprendizado com seus erros. Olhares Amazônicos, 5(2), 1048-1057. https://ufrr.br/roa/index. $\mathrm{php} / \mathrm{component/phocadownload/category/61-volume-}$ 5?download $=603$ : numero- 2

Tyler, K. A., Handema, R., Schmitz, R. M., Phiri, F., Kuyper, K. S., \& Wood, C. (2016). Multi-level risk and protective factors for substance use among Zambian street youth. Substance Use \& Misuse, 51(7), 922-931. https://doi.org/10.3109/10826084 .2016 .1156702

Waiselfisz, J. J. (2015). Mapa da Violência 2015: Adolescentes de 16 e 17 anos no Brasil. Flacso. http://flacso.org.br/files/2017/04/ mapaViolencia2015_adolescentes-1.pdf

World Health Organization. (2000). Modulo 3 - Understanding substance use among street children. In World Health Organization, Working with street children: A training package on substance abuse, sexual and reproductive health including HIV/AIDS and STDs (pp. 1-56). World Health Organization. http://apps.who.int/iris/bitstream/handle/10665/66756/WHO MSD MDP 00.14 Module3.pdf;jsessionid=0091A126AB1 $\overrightarrow{\mathrm{A}}$ A075DC1CE-1D2203AA722? sequence $=4$ 